\title{
Attitudes of sports medicine physicians about defensive medicine practices
}

\section{Spor hekimlerinin defansif tıp uygulamaları konusundaki tutumları}

\author{
Sabriye Ercan (D), Ayhan Canbulut (iD), Hüseyin Tolga Acar (D), Esma Arslan (D), Cem Çetin (D) \\ Sports Medicine Department, Faculty of Medicine, Suleyman Demirel University, Isparta, Turkey
}

\section{ABSTRACT}

Objective: This study has been designed to examine the level of knowledge and attitudes of sports medicine physicians on defensive medicine practices.

Materials and Methods: Physicians working as sports medicine specialists in public institutions and residents receiving specialization education in sports medicine at various universities in Turkey were included in this study. The descriptive information form prepared by the researchers and the Defensive Medicine Behaviour Scale were applied to the participants.

Results: One hundred fifteen sports medicine physicians (male: $n=90,78.3 \%$; female: $n=25,21.7 \%$ ) participated in the study. While $33 \%$ ( $n=38$ ) of the participants were residents in sport medicine specialty programs, $42.6 \%(n=49)$ of the participants were specialists, $7.8 \%(n=9)$ had title of assistant professor, 2.6\% ( $n=3)$ associate professor and 13.9\% $(n=16)$ professor of sports medicine. Physicians over 39 years of age $(p=0.0001)$ and physicians with 14 or more years of professional experience in sports medicine $(p=0.03)$ were significantly different among sports medicine physicians in terms of working in sports clubs and the private sector. While $49.6 \%(n=57)$ of the sports medicine physicians declared that they regularly took out the compulsory financial liability insurance for medical malpractice every year, $20.9 \%(n=24)$ of the sports medicine physicians had never done it up to date. Those who stated that they had heard of the concept of defensive medicine practices were younger $(36 \pm 8.9$ versus $41 \pm 11.2$, $p=0.02)$ and their professional experience was shorter $(11.7 \pm 8.9$ versus $16.9 \pm 11, \mathrm{p}=0.01)$. Sports medicine physicians had a moderate attitude towards defensive medical practices. The participants" level of knowledge about defensive medicine practices, their academic level and gender brought up a significant difference in the replies of questionnaire $(p<0.05)$.

Conclusion: Despite working in a relatively low-risk specialization in terms of malpractice cases, sports medicine physicians perform defensive medicine practices at a moderate level in their clinical practice. Furthermore, sports medicine physicians' knowledge about defensive medicine practices is insufficient.

Keywords: Defensive medicine, sports medicine, malpractice, forensic medicine

öz

Amaç: Bu çalışma, spor hekimlerinin defansif tıp uygulamaları konusundaki bilgi düzeylerini ve tutumlarını incelemek üzere tasarlanmıştır.

Gereç ve Yöntemler: Çalışmaya, kamu kurumlarında spor hekimliği uzmanı olarak çalışan hekimler ve çeşitli üniversitelerde Spor Hekimliği alanında tıpta uzmanlık eğitimi alan araștırma görevlileri dahil edilmiștir. Katıımcılara, araștırmacılar tarafından hazırlanan tanımlayıcı bilgi formu ve 'Defansif Tıp Uygulamaları Anketi' uygulanmıştır.

Bulgular: Araştırmaya, 115 (erkek: n=90, \%78.3; kadın: n=25, \%21.7) spor hekimi katımıştır. Katılımcıların \%33 (n=38)'ü Arş. Gör. Dr., \%42.6 (n=49)'sı Uzman Dr., \%7.8 (n=9)'i Dr. Öğr. Üyesi, \%2.6 ( $n=3)^{\prime}$ 's Doç. Dr. ve \%13.9 (n=16)'u Prof. Dr. unvanına sahiptir. Spor hekimleri arasında, 39 yașın üzerinde $(p=0.0001)$ olan hekimler ile spor hekimliği alanında 14 ve üzeri yıl mesleki tecrübesi $(p=0.03)$ olan hekimler, spor kulüplerinde ve özel sektörde görev alma bakımından istatistiksel olarak anlamlı fark oluşturmuşlardır $(\mathrm{p}<0.05)$. Spor hekimlerinin \%49.6 ( $n=57$ )'sı her yıl düzenli olarak tıbbi kötü uygulamaya ilișkin zorunlu mali sorumluluk sigortası yaptırdığını, \%20.9 $(n=24)^{\prime} u$ ise bugüne kadar hiç yaptırmadığını beyan etmiștir. Defansif tıp uygulamaları kavramını daha önce duyduğunu beyan edenlerin yaşlarının daha genç (36 \pm 8.9 'a karşı 41 $\pm 11.2, p=0.02)$ ve hekimlik sürelerinin daha kısa $(11.7 \pm 8.9$ 'a karşı $16.9 \pm 11, p=0.01$ ) olduğu gözlemlenmiștir. Ankete verilen cevaplara göre spor hekimlerinin orta düzeyde defansif tıp uygulamaları tutumu gösterdiği belirlenmiştir. Anketin bazı sorularına verilen cevaplarda; katılımcıların defansif tıp uygulamaları konusundaki bilgi düzeyi, akademik seviyeleri ve cinsiyetleri fark oluşturmuştur $(p<0.05)$.

Sonuç: Spor hekimleri, malpraktis davaları açısından nispeten düşük riskli bir branşta çalışmalarına rağmen klinik pratiklerinde, defansif tıp uygulamalarına orta düzeyde bașvurmaktadırlar. Ayrıca, spor hekimlerinin defansif tıp uygulamaları konusundaki bilgilerinin yeterli olmadığı görülmüștür.

Anahtar Sözcükler: Defansif tıp, spor hekimliği, malpraktis, adli tıp

\section{INTRODUCTION}

The concept of defensive medicine practices emerged for the first time in the United States in the late 1970s. It has been mentioned with terms such as "defensive medicine", "recessive medicine", "cautious medicine", and "precauti- onary medicine" and has taken its place in the literature (1). Defensive medicine practices represent any kind of medical practices that aim to avoid medical malpractice that is increased significantly in recent years. These are defined as 
"practices in which the physician"s priority is to prefer unnecessary advanced diagnostic tests, treatments and clinical procedures to avoid being sued by the patient rather than determining the patient"s diagnosis and treating him/her" (2). According to another definition, defensive medicine has been expressed as "physician practices in which treatment is considered to be legal and recommended, although it is scientifically known that there is no optimal treatment option for the patient" (3). The common and most basic feature of defensive medicine practices in all the definitions mentioned above is the presence of the physician"s self-protective behavior against any possible risk of litigation from the patient. As a result of this main defensive behavior, the physician performs medical procedures for diagnosis and treatment, which can be considered unnecessary (1). However, the technology that has been developing rapidly in recent years has also affected the field of medicine, and especially the role of imaging methods in the diagnosis and treatment of many diseases are coming into prominence in medical practice. Nevertheless, unnecessary imaging tests, interventional procedures such as biopsy and surgical interventions such as cesarean section can physically and emotionally harm the patient and also increase the health expenditures (4).

Increases in the number of lawsuit cases against physicians have caused physicians to develop the principle of "first do no self-harm" rather than "first, do no harm" due to reasons such as anxiety about filing a lawsuit against them, fear of not being able to make the correct diagnosis, becoming the target of violence by patients" relatives, fear of being complained about, and not being able to cope with the pressures from administrative management (5). When studies in the literature are examined, it is observed that defensive medicine practices are evaluated in two basic groups, called positive defensive medicine and negative defensive medicine practices (1). Positive defensive medicine is the effort to complete the procedures necessary for diagnosis or treatment and to do various practices to strengthen the defense of the physician against a possible lawsuit (6). During positive defensive medicine practices, the physician carries out operations that are not considered medically necessary, exaggerates the necessary procedures, or emphasizes more the debt of care that he/she has not been able to adequately show to his/her patients in his/her professional background in order to protect himself/herself (1). Negative defensive medicine includes situations in which physicians stop providing the necessary services to patients and avoid diagnostic and treatment procedures that may be considered risky due to their liability concerns (7). Negative defensive medicine emerges as a result of avoiding the medically necessary practices (6).
This study"s aim is to examine the knowledge levels and attitudes of sports medicine physicians working in our country towards defensive medicine practices.

\section{MATERIAL and METHODS}

The study was approved by the local ethics committee. The population of the study is composed of sports medicine specialists working in public or private health institutions and residents of sports medicine at various medical faculties in Turkey. It was determined that the research results should reach 114 participants to reflect the population at a 99\% confidence level (precision rate of 0.05 ).

The participants were asked to fill out the descriptive information form prepared by the researchers and the Defensive Medicine Behaviour Scale (8).

\section{The Defensive Medicine Behaviour Scale (DMBS)}

The DMBS was developed by Başer et al. (Cronbach"s alpha $=0.853$ ) (8) and is used to measure knowledge, attitudes, and behaviors concerning defensive medicine. The behavior-oriented items consisted of 9 positive and 5 negative defensive medicine questions with a 5-point scale ranging from 1 (completely disagree) to 5 (completely agree). The total scores were calculated for each participant (min. 14; max. 70). Four closed-ended questions (yes/no) were used to measure the levels of knowledge. The "completely agree", "strongly agree", and "moderately agree" options were categorized as "yes," while the "disagree" and "completely disagree" responses were categorized as "no" to ensure the precision of the responses (8).

\section{Statistical analysis}

SPSS v23 package program was used for statistical analysis. The frequency, percentage distributions, and descriptive statistical analyses of the data were performed. Differences in categorical variables were evaluated using the chi-square independence test. Differences between two independent groups were evaluated by Student"s t-test, and differences between three or more groups were evaluated by the oneway ANOVA test. In case of a difference in multiple comparisons, the group from which the difference originated was determined by post hoc tests. The data are presented as n, $\%$, and mean \pm standard error (min-max). The P-value was accepted to be significant at a 0.05 level.

\section{RESULTS}

One hundred fifteen sports medicine physicians (male: $\mathrm{n}=90,78.3 \%$; female: $\mathrm{n}=25,21.7 \%$ ) participated in the study. While $33 \%(n=38)$ of the participants had the title of Res. Asst., $42.6 \%(\mathrm{n}=49)$ of the participants were specialist, $7.8 \%(\mathrm{n}=9)$ of the participants were Asst. Prof., $2.6 \%(\mathrm{n}=3)$ of the participants were Assoc. Prof., and 13.9\% $(n=16)$ of 
them had the title of Professor. The mean age of the participants was 37.2 \pm 0.9 (25-70) years, the total time in the medical profession was $12.9 \pm 0.9$ years (0.2-45), and the working time in the field of sports medicine was $9.3 \pm 0.8$ (0.1-40) years (Table 1).

\begin{tabular}{|c|c|c|}
\hline Gender (M/F) & $\begin{array}{c}\% \\
78.3 / 21.7\end{array}$ & $\begin{array}{c}n \\
90 / 25\end{array}$ \\
\hline \multicolumn{3}{|l|}{ Titles } \\
\hline Resident & 33 & 38 \\
\hline Specialist & 42.6 & 49 \\
\hline Assistant Professor & 7.8 & 9 \\
\hline Associate Professor & 2.6 & 3 \\
\hline \multirow[t]{2}{*}{ Professor } & 13.9 & 16 \\
\hline & Mean \pm SE & Min-Max \\
\hline Mean age (years) & $37.2 \pm 0.9$ & $25-70$ \\
\hline Total medical profession time (years) & $12.9 \pm 0.9$ & $0.2-45$ \\
\hline $\begin{array}{l}\text { Working time in sports medicine (years) } \\
\text { M: Male, F: Female, SE: standart error. }\end{array}$ & $9.3 \pm 0.8$ & $0.1-40$ \\
\hline
\end{tabular}

While $80.9 \%$ ( $n=93)$ of the sports medicine physicians work in governmental health institutions, 6.1\% $(n=7)$ work in sports clubs, $7.8 \%(n=9)$ work both in governmental health institutions and sports clubs, $1.7 \%(\mathrm{n}=2)$ work in private health institutions, $0.9 \%(n=1)$ work both in governmental and private health institutions, and $2.6 \%(n=3)$ of the participants work both in sports clubs and private health institutions (Figure 1). Female physicians were younger $(p=0.004)$, and professional experience $(\mathrm{p}=0.01)$ was shorter. All of the female physician participants work in governmental health institutions. Physicians over 39 years of age $(p=0.0001)$ and physicians with 14 or more years of professional experience in sports medicine $(\mathrm{p}=0.03)$ were significantly different in terms of working in sports clubs and the private sector.

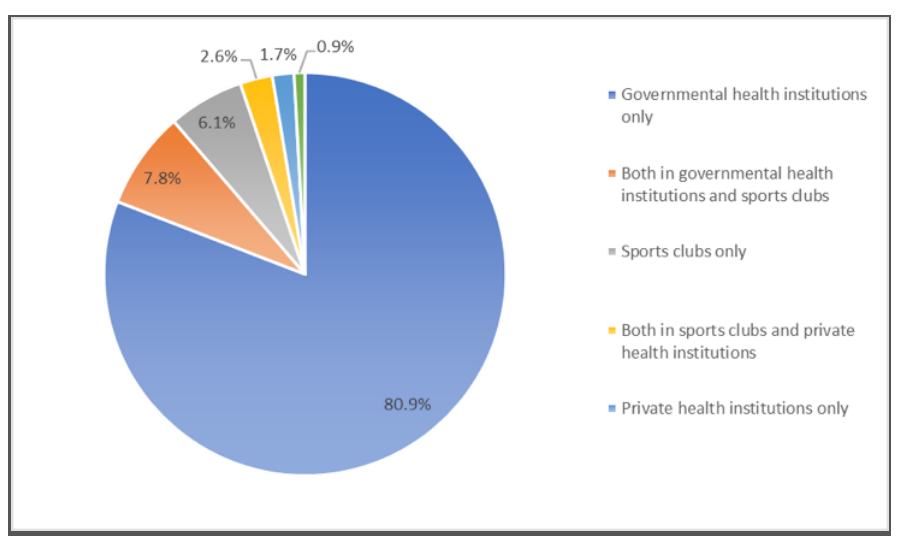

Figure 1. Institutions where sports medicine physicians work

The participants" working time was calculated to be $38.5 \pm 0.6$ (7-60) hours/week in governmental health institutions, $28.8 \pm 3.8$ (1-70) hours/week in sports clubs, and $37.6 \pm 4.5$ (1-60) hours/week in private health institutions. The mean number of patients/athletes examined by the sports medicine physicians participating in the study is $67.6 \pm 5.4(1-300) /$ week.
While $49.6 \%(n=57)$ of the sports medicine physicians declared that they regularly took out the compulsory financial liability insurance for medical malpractice every year, $20.9 \%(n=24)$ of the participants declared that they had never had it done to date. The answers of the participants to the questions measuring the level of knowledge about defensive medicine practices are presented in Table 2. The physicians who stated that they had heard about the concept of defensive medicine practices were younger $(36 \pm 8.9$ versus $41 \pm 11.2, p=0.02$ ), and their medical profession was shorter $(11.7 \pm 8.9$ versus $16.9 \pm 11, \mathrm{p}=0.01)$. The physicians who reported that they had heard of this concept had higher scores on the $9^{\text {th }}$ and $10^{\text {th }}$ questions of the questionnaire (2.9 \pm 1.2 versus $2.3 \pm 1.2, p=0.02 ; 2.6 \pm 1.2$ versus $2.1 \pm 1.1$, $\mathrm{p}=0.049$, respectively).

The number of participants who answered the first question of the questionnaire; "I do not have sufficient information about the content of the defensive medicine practices concept" as "moderately agree (3 points)" were significantly higher $(p=0.02)$ than those who replied as they had sufficient information "completely disagree (1 point)." The scores given to the $10^{\text {th }}$ question of the questionnaire (2.6 \pm 1.1 versus $2 \pm 1.1$ ) by the physicians who stated that they did not have sufficient information about the content of this concept were also higher $(\mathrm{p}=0.03)$.

Table 2. The level of knowledge of sports medicine physicians about defensive medicine practices

\begin{tabular}{|c|c|c|}
\hline & & \\
\hline & $\%$ & $n$ \\
\hline $\begin{array}{l}\text { as a lawsuit been filed due to malpractice during your } \\
\text { edical profession? }\end{array}$ & 2.6 & 3 \\
\hline $\begin{array}{l}\text { you think that you will be sued for malpractice } \\
\text { thin } 10 \text { years? }\end{array}$ & 17.4 & 20 \\
\hline $\begin{array}{l}\text { ave you heard of the concept of defensive medicine } \\
\text { actices before? }\end{array}$ & 75.7 & 87 \\
\hline $\begin{array}{l}\text { you have sufficient information about the content of } \\
\text { concept of defensive medicine practices? }\end{array}$ & 21.7 & 25 \\
\hline
\end{tabular}

According to the responses given to the Defensive Medicine Behaviour Scale, sports medicine physicians had a moderate attitude towards defensive medical practices. Physicians tended to explain medical practices in more detail, keep records more detailed and allocate more time to patients in order to protect themselves from legal problems (Table 3).

The answer of "completely disagree (1 point)" given by professors to the second question of the questionnaire was found to be at a higher rate compared to the answers given by residents and specialists $(\mathrm{p}=0.04)$. The physicians who did not think that they would be sued due to malpractice in the next ten years gave the answer "completely disagree (1 point)" and "disagree ( 2 points)" to the second question of the questionnaire $(p=0.005)$. The mean score given by the phy-

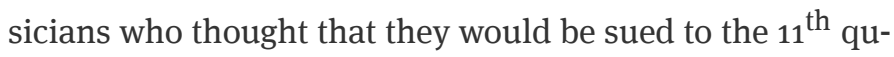


estion of the questionnaire was higher (3.7 \pm 1 versus $2.9 \pm 1.2$ ) and made a difference $(\mathrm{p}=0.006)$. Furthermore, the scores given by professors to the $11^{\text {th }}$ question were lower than the scores given by residents and specialists $(\mathrm{p}=0.02)$.

The sports medicine physicians who had heard of the concept of defensive medicine practices before answered the $3^{\text {rd }}$ question of the questionnaire as "strongly agree (4 points)", $(\mathrm{p}=0.03)$.

The difference in the attitude between professors and residents and specialists was determined in the answers given to the $8^{\text {th }}$ question of the questionnaire. Professors reported that they did not avoid examining patients with complex medical problems at a higher rate than residents and speci- alists $(p=0.02)$. The rate of the physicians who replied that they did not have sufficient information about the content of the concept of defensive medicine practices to the $8^{\text {th }} \mathrm{qu}$ estion as "moderately agree (3 points)," ( $p=0.02)$.

Female physicians showed a higher tendency to avoid treatment protocols with higher complication rates $(p=0.03)$. The answer of "completely disagree (1 point)" given by professors to the same question at a higher rate than the answers given by residents $(\mathrm{p}=0.048)$. Furthermore, the physicians who stated that they had sufficient information about the content of the concept of defensive medicine practices gave the answer of "completely agree ( 5 points)" to the $9^{\text {th }}$ question at a higher rate $(\mathrm{p}=0.02)$.

\section{Table 3. Answers to the Defensive Medicine Behaviour Scale}

\section{Questions}

1 In order to be protected from legal problems, I want examinations other than what I deem necessary from my patients.

2 In order to be protected from legal problems, I prescribe most of the drugs I can prescribe to my patients within the indications.

3 I want more consultations in order to be protected from legal problems

4 I explain medical practices to my patients in more detail in order to protect them from legal problems.

5 I am spending more time with my patients in order to be protected from legal problems.

6 I keep the health records in more detail in order to be protected from legal problems.

7 I avoid patients who are likely to sue in order to be protected from legal problems

8 I avoid patients with complex medical problems in order to avoid legal problems.

9 To avoid legal problems, I avoid treatment protocols with high complication rates.

$\mathbf{1 0 l}$ tend to prefer non-invasive procedures instead of invasive procedures in order to avoid legal problems.

11 As malpractice cases find a lot of media coverage, I feel uneasy in my medical practice Total score

The effect of gender on the attitude was also observed in the $11^{\text {th }}$ question. The mean score obtained by female physicians $(3.5 \pm 1.2)$ was found to be higher in comparison with male counterparts $(2.9 \pm 1.2),(\mathrm{p}=0.04)$.

The total score of the questionnaire decreased as the academical degree has been progressed. The total score $(24.3 \pm 8.9)$ of professors differed from the total scores of residents (31.3 \pm 6.1$)$ and specialists $(31.5 \pm 7.8),(p=0.01)$. Interestingly, the institutions where sports medicine physicians worked (sports clubs, governmental or private health institutions) did not make any difference in the examined factors and questionnaire results ( $\left.\mathrm{p}^{>} 0.05\right)$.

\section{DISCUSSION}

The rapid renewal of medical knowledge and the development of medical technologies motivate physicians to try some clinical practices that they could not perform in the past. As a result of these practices, which may involve severe risks, the number of malpractice notifications and legal cases are increasing (9). It was reported that malpractice cases were ranging between $10.5 \%$ to $12.3 \%$ annually $(6,10)$ in Turkey. Therefore, the importance of the compulsory financial liability insurance regarding the legally determined medical malpractice, which can enable physicians to feel secure is increasing. The "Compulsory Financial Liability Insurance for Medical Malpractice," which came into force in Tukey in 2010 and has been compulsory since then, varies according to the risk groups. Studies point out the possibility of erroneous practices leading to harmful results cannot be underestimated (11). It has been found that physicians feel safe and experience less anxiety of encountering malpractice cases if they pay insurance premium $(11,12)$. While $49.6 \%(n=57)$ of the sports medicine physicians declared that they regularly took out the compulsory financial liability insurance for medical malpractice every year, $20.9 \%(n=24)$ of them had never done it to date. The insurance rate of the sports medicine physicians participated in this research was found to be relatively low compared to the literature (11, 13). The reason for that can be performing less risky clinical practices in sports medicine compared to other specialties, especially surgical branches. In a study conducted among 190 physicians at Atatürk University Hospital in 2020, 15.7\% of the physicians who participated in the study declared that they had the compulsory financial insurance (14). The fact that physicians working in various departments took part in the related study can be shown as the reason for this proportional difference.

In a research conducted using the same scale in 2014 with 88 participants, mostly consisting of general practitioners, $64.2 \%$ of the participants had heard of the concept of defensive medicine practices before, and $28.4 \%$ of the participants had sufficient knowledge about defensive medicine practices (9). In another study in the literature conducted on psychiatrists, it was reported that approximately three-quarters of psychiatrists worked in a manner that adopted defensive medicine practices in the past month (15).

It was emphasized that with a well-structured education process that examined reasons in depth, defensive practices might have been decreased (15). In light of our study and the information in 
the literature $(5,6,9,16,17)$, concept of defensive medicine practices is heard by many physicians but is not known sufficiently yet, and it is necessary to organize defensive medicine training programs for physicians in any period, especially at the beginning of their professional life.

According to the responses given to the Defensive Medicine Behaviour Scale, the sports medicine physicians who participated in the current research had a moderate attitude towards defensive medicine practices. In various studies, the attitude levels of different degrees towards defensive medicine practices were specified. In a research conducted on 173 physicians working in internal and surgical disciplines in the city center of Konya, the attitude of the physicians participating in the study towards defensive medicine practices was found to be moderate, similar to our research (17). In the same study, it was found that the majority of the physicians (93.6\%) performed defensive medicine practices (17). In two different studies carried out on family medicine physicians in Konya and Izmir, this rate was determined to be $78.38 \%$ and $93.8 \%$, respectively $(9,10)$. Defensive medicine practices have been increasing rapidly, especially in recent years.

In this study, the rate of suing sports medicine physicians for malpractice at any time in their professional life was determined to be $2.6 \%(n=3)$. In a study conducted in Turkey, physicians, especially in surgical branches, faced 4.6 times more malpractice cases than physicians in internal branches (17). In a survey applied to 457 physicians working in internal and surgical branches in Taiwan, it was observed that $56.5 \%$ of the physicians had the experience of encountering cases due to malpractice at any time (18). In another study carried out with 877 physician participants in Israel, it was determined that $25 \%$ of the physicians had a malpractice case at least once in their career (16). In a different field study conducted among physicians in Turkey, the rate of lawsuits was found to be $12.34 \%$ (10).

Defensive medicine practices under 40 years of age were found to be significantly higher compared to physicians over 40 years of age $(19,20)$. However, according to Catino, young physicians resort to defensive medicine practices more frequently due to the lack of professional experience (21). In another study carried out in Turkey, the mean scores of resident physicians who were in the first two years of their residency were found to be significantly higher than those who were in the last two years of their residency (17). Likewise, professors who participated in this research expressed that they were not avoiding the cases with complex medical problems compared to residents and specialists $(p=0.02)$. This difference may be ascribed to professional experience acquired with academical progress. Moreover, the age of $39(p=0.0001)$ and professional experience $(\mathrm{p}=0.03)$ in sports medicine have been found to lead to a statistically significant difference. It can be inferred from this result that a certain level of professional experience may be considered as a threshold in terms feeling ready and confident, especially regarding the team physicians' practices.

This study revealed that female sports physicians tend to avoid treatment protocols which have high complication rates $(p=0.03)$. In a study conducted in Turkey, the positive, negative, and total defensive mean scores of male physicians were significantly higher than those of female physicians (17). In the research conduc- ted by Moosazadeh et al., female physicians preferred defensive medicine compared to their male counterparts (22). However, in some studies, no significant relationship was determined between gender and rates of defensive medicine practices $(20,23)$.

Contrary to the predictions, sports medicine physicians working as team doctors in sports clubs exhibit a similar defensive medicine approach like the other sports medicine physicians.

It is very important that sports caregivers must take affirmative steps that better protect their patients from harm and physicians from legal liability (24).

Although our study is the first to examine the attitudes of sports medicine physicians in Turkey towards defensive medicine practices, survey study design may have affected the results. It is clear that there is a need for studies to be conducted using qualitative research techniques.

\section{CONCLUSION}

Even though the sports medicine is regarded as a low-risk branch in terms of malpractice, the frequency of defensive medicine practices was found to be at a significant level. The possible cause for this situation may be vitality of the detailed pre-participation evaluations to secure athlete's health and life. At the same time, medical malpractice that may lead to terminate the careers of athletes can increase the frequency of sports medicine physicians who apply to defensive medicine practices. Furthermore, it was observed that sports medicine physicians did not have sufficient information about defensive medicine practices. Therefore, forensic specialists, jurists, sports medicine specialists with high professional experience and other stakeholders should share information and experience via educational programs and seminar to develop a relevant attitude based on the principle of 'first, do no harm.'

\section{Conflict of Interest / Çıkar Çatışması}

The authors declared no conflicts of interest with respect to authorship and/or publication of the article.

\section{Financial Disclosure / Finansal Destek}

The authors received no financial support for the research and/or publication of this article.

\section{REFERENCES}

1. Yeşiltaş A, Erdem R. Defansif tıp uygulamalarına yönelik bir derleme. Süleyman Demirel Üniversitesi Vizyoner Dergisi. 2018;10(23):137-50.

2. Hermer LD, Brody H. Defensive medicine, cost containment, and reform. J Gen Intern Med. 2010;25(5):470-3.

3. Harding AJ. "Informed consent" and disclosure of risks in medical treatment: some recent developments. Ann Acad Med Singapore. 1987;16(2):375-9.

4. Sethi M, Aseltine R. Investigation of defensive medicine in Massachusetts. Mass Medical Soc. 2008.

5. zata M, Kubilay Ö, Akkoca Y. Konya il merkezinde çalışan hekimlerde defansif (çekinik) tıp uygulamalarının araştırılması. Gümüşhane Üniversitesi Sağlık Bilimleri Dergisi. 2018;7(1):131-8.

6. Selçuk M. Çekinik (defansif) tıp. İzmir Üniversitesi Sosyal Bilimler Enstitüsü Sağlık Hukuku Yüksek Lisans Tezi. İzmir: İzmir Üniversitesi; 2015.

7. van Dijck G. Assessing the defensive practices concern in tort law: bridging the gap between empirical analysis and doctrinal reasoning. Tilburg Law School Research Paper. 2013(012).

8. Başer A, Başer Kolcu Mi, Kolcu G, Gök Balcı U. Defansif tıp uygulamaları tutum ölçeğinin Türkçe formunun geçerlilik ve güvenilirliği: ön çalışma. Tepecik Eğit Hast Derg. 2014;24(2):99102. 


\section{S. Ercan, A. Canbulut, H. T. Acar, et. al.}

9. Baser A, Kolcu G, Çı̆ğıgil Y, Kadınkız B, Öngel K. İzmir Karşıyaka ilçesinde görev yapan aile hekimlerinin defansif tıp uygulamaları ile ilgili görüşlerinin değerlendirilmesi. Smyrna Tıp Dergisi. 2014;16:24.

10. Aynacı Y. Hekimlerde defansif (çekinik) tıp uygulamalarının araştırıması. Selçuk Üniversitesi Meram Tıp Fakültesi Adli Tıp Ana Bilim Dalı Uzmanlık Tezi. Konya: Selçuk Üniversitesi; 2008.

11. Kerç E, Akpınar Ö. Türkiye'de uygulanmakta olan hekim mesleki sorumluluk sigortalarına yönelik bir araștırma. Öneri. 2018;13(50):229.

12. Gökmen H, Güleç S. Tıbbi malpraktis riskinin yönetiminde bir araç olarak hekim mesleki sorumluluk sigortaları. Sağlıkta Performans ve Kalite Dergisi. 2010;1(1):9-16.

13. Kasap H, Akar T, Demirel B, Dursun AZ, Sarı S, Özkök A, et al. The change of preference priorities on examination for specialty in medicine by years of high risky medical branches in medical malpractice. Bull Leg Med. 2015;20(1):34-7.

14. Calikoglu EO, Aras A. Defensive medicine among different physicians' disciplines: A descriptive cross-sectional study. J Forensic Leg Med. 2020:101970.

15. Passmore K, Leung WC. Defensive practice among psychiatrists: a questionnaire survey. Postgrad Med J. 2002;78(925):671-3.

16. Asher E, Greenberg-Dotan S, Halevy J, Glick S, Reuveni H. Defensive medicine in Israel-a nationwide survey. PLoS One. 2012;7(8): e42613.

17. Göçen Ö, Yllmaz A, Aslanhan H, Celepkolu T, Tuncay S, Dirican E. Assistant physicians knowledge and attitudes about defensive medical practices, work-related stress and burnout levels. TJFMPC. 2018;12(2):77-87.
18. Chen K-Y, Yang C-M, Lien C-H, Chiou H-Y, Lin M-R, Chang H-R, et al. Burnout, job satisfaction, and medical malpractice among physicians. Int J Med Sci. 2013;10(11):1471.

19. Ortashi O, Virdee J, Hassan R, Mutrynowski T, Abu-Zidan F. The practice of defensive medicine among hospital doctors in the United Kingdom. BMC Med Ethics. 2013;14(1):42.

20. Solaroglu I, Izci Y, Yeter HG, Metin MM, Keles GE. Health transformation project and defensive medicine practice among neurosurgeons in Turkey. PloS One. 2014;9(10): e111446.

21. Catino M. Why do Doctors practice defensive medicine? The side-effects of medical litigation. Saf Sci Mon. 2011;15(1):1-12.

22. Moosazadeh M, Movahednia M, Movahednia N, Amiresmaili M, Aghaei I. Determining the frequency of defensive medicine among general practitioners in Southeast Iran. Int J Health Policy Manag. 2014;2(3):119.

23. Tanriverdi O, Cay-Senler F, Yavuzsen T, Turhal S, Akman T, Komurcu S, et al. Perspectives and practical applications of medical oncologists on defensive medicine (SYSIPHUS study): a study of the Palliative Care Working Committee of the Turkish Oncology Group (TOG). Med Oncol. 2015;32(4):106.

24. Kane SM, White RA. Medical malpractice and the sports medicine clinician. Clin Orthop Relat Res.2009;467(2):412-9. 